\title{
CAMUS „PROMÉTHEUSZ A POKOLBAN” CÍMŰ ESSZÉJÉNEK ELEMZÉSE
}

\section{Szerzők:}

Pavlovics Zsófia

Debreceni Egyetem

Szerző e-mail címe:

zsofikuszi@gmail.com

\section{Lektorok:}

Mező Katalin (PhD)

Debreceni Egyetem

Mező Ferenc (PhD)

Eszterházy Károly Katolikus Egyetem

...és további két anonim lektor

\begin{abstract}
Absztrakt
Ez a tanulmány Albert Camus (1913-1960) 1946-os „Prométheusz a pokolban” címú esszéjére összpontosít. Prométheusz mítoszának alapeleme a lázadás, és ez a tanulmány bemutatja, hogyan lehet összekapcsolni az író munkásságát és történelmi hátterét (tekintve, hogy Camus a francia összeomlás kezdete óta ellenezte a nácizmussal való együttmûködést).
\end{abstract}

Kulcsszavak: Camus, Prométheusz

Diszciplina: irodalomtudomány

\begin{abstract}
ANALYSIS OF CAMUS'S ESSAY "PROMETHEUS IN HELL"

This study focuses on the essay 'Prometheus in Hell' from 1946 by Albert Camus (19131960). The basic element of Prometheus's myth is rebellion, and this study shows how the writer's work and historical background can be linked (considering that Camus had been opposed to cooperation with Nazism since the early days of the French collapse).
\end{abstract}

Keywords: Camus, Prometheus

Discipline: Literary Studies

Pavlovics Zsófia (2021): Camus „Prométheusz a pokolban” című esszéjének elemzése. Lélektan és hadviselés - interdiszciplináris folyóirat, III. évf. 2021/1. szám. 83-93. doi: 10.35404/LH.2021.1.83 
A 20. századi francia irodalom és filozófia egyik legismertebb alakja Albert Camus, aki tragikus és nehézségekkel teli magánélete ellenére jelentős munkásságot hagyott az utókorra. Camus édesapja korán meghalt, írástudatlan édesanyja nagy szegénységben nevelte gyermekeit. Tanárai támogatásával járhatott középiskolába, majd egyetemre. Újságíróként kezdett dolgozni, előbb Algírban, majd Párizsban, ahol csatlakozott az ellenállási mozgalomhoz. Íróként eközben egyre nagyobb sikereket ért el: Közöny címú művét 1942-ben, Sziszzüphosz mitosza című esszéjét 1943-ban jelentette meg. Félreértés (Caligula) című drámáját 1944-ben játszották. 1957-ben Nobeldíjat kapott. Az irodalom mellett a filozó-fia, azon belül is főleg az egzisztencializmus egyik meghatározó alakja volt (de Luppé, 1958).

Jelen tanulmány Camus Prométheusz a pokolban címú esszéjét elemzi, mely görög mitológiai témát dolgoz fel. Mindenekelőtt fontos tisztázni a mítosz és a mitológia fogalmát. A mítosz istenekről, természetfeletti lényekről szóló legenda, mely vallási elemeket tartalmaz és betekintést enged az őket kitaláló nép életébe és annak kultúrájába, esetünkben az ókori Görögország és görögök hitvilágába.

\section{Mítosz és mitológia}

Mircea Eliade (2014: 69) román vallástörténész, filozófus és író szerint: „A mítosz valamilyen új kozmikus helyzet vagy őseredeti esemény jelentkezését adja tudtul. Tehát mindig valamilyen teremtésről szóló beszámoló. Elbeszéli, miként vittek véghez valamit, miként kezdett ez létezni; csak a valóságról beszél, ami valóban végbement, és teljesen megnyilvánult.” Az ezzel szorosan összekapcsolódó fogalom, a mitológia pedig a mítoszok összességére vonatkozik, azok történetével, eredetével, valóságalapjával foglalkozik.

A mitológia és mítosz fogalmainak definiálása mellett fontos kitérni irodalmi vonatkozásaikra is, hiszen a 20. század irodalmában nem volt újkeletű a felhasználásuk. Már a reneszánsz francia irodalomban többen viszszatértek az antik költészethez, mint például Pierre de Ronsard és Joachim du Bellay. A klasszikus színház gyakran használt antik témákat. Ide sorolhatjuk Racine darabjait: $A n$ dromakhé (1667), Iphigeneia (1674), Phaedra (1677). Pierre Corneille, Médea című tragédiáját 1635-ben, az Andromédát 1650-ben, az Oidipuszt 1659-ben adták ki. A Diderot és d'Alambert által szerkesztett Enciklopédiában külön szócikkben említették a „mítosz” kifejezést. A 19. században a romantika hívei elsősorban a középkor felé fordulnak, de nagy szerepet játszik körükben az orientalizmus is (Hugo, Nerval).

A parnasszista költők előszeretettel dolgoznak fel mitológiai (görög, indiai) témákat, például Leconte de Lisle, Téophile Gautier, Théodore de Banville. A 20. században Jean Giraudoux a Trójában nem lesz báború című színpadi múvében az Iliászt értelmezi újra: egy olyan Európát ábrázol benne, mely bár látja a háború közeledtét, nem tehet semmit ellene (Louviot, 2013).

\section{Prométheusz mítosza}

Az itt elemezni kívánt filozófiai esszének Prométheusz mítosza adja az alapját. Prométheusz Iapetosz titán és Themisz fia. Zeusz fellázadt Prométheusz apja, Kronosz ellen és Prométheusz a legtöbb titánnal ellentétben apja védelmére kelt. Prométheusz az emberek pártját fogta az istenek helyett. Az embereket 
egy legenda szerint Prométheusz teremtette meg agyagból és vízből. Megtanította őket szántás-vetésre, mesterségekre, írásra, kórok gyógyítására és ellopta számukra a parazsat az égből, melyet korábban Zeusz megvont tőlük, amiért Prométheusz rávette, hogy az áldozati állatok értéktelenebb részeit válasszák az istenek számára.

Zeusz bosszút állt mindazért, amit Prométheusz az emberekért tett: a Kaukázus szikláihoz láncolta, ahol egy keselyú naponta kitépte a máját, az azonban minden nap újra nőtt. A titán Héraklész segítségével szabadult meg, aki lelőtte a keselyűt, Prométheuszt pedig eloldozta. Héraklésznak erre azért volt lehetősége, mert elárult apjának egy titkot: nem születhet fiú gyermeke, mert ha Thetisz fiút szül, a gyermek hatalmasabb lesz apjánál is (Csiffáry 2008).

Prométheusz mítosza nemcsak Camus eszszéjében található meg, hanem számos egyéb múben is fellelhetô a francia irodalomban. Ballanche Orpheusz címû mûvében magyarázza Prométheusz mítoszát: Prométheusz hatalmat adott az embernek arra, hogy „megszelidítse a vak természetet” és „elhozta a földre a haladás törvényét", ő képviseli az emberi faj fokozatos haladását. A 19. századi írók általában a nagy találmányok előfutárának tartották a titánt.

Jules Michelet történetírói munkájának előszavában pedig így fogalmaz: „Az ember saját magának Prométheusza." (idézi Michele-t Albouy, 1969, 161. o.). Pierre Albouy így értelmezi Michelet Prométheusszal kapcsolatos gondolatait: A haladás, mely felszabadítja az emberiséget, pontosabban létrehozza és megalkotja, lázadás formájában történik (lásd: Albouy 1969, 161. o.). Ezután azt írja, hogy
Michelet Az emberiség Bibliája című művében a királyi despotizmus elleni harcot a kereszténység elleni harcnak rendeli alá, mely véleménye szerint egy, a demokráciával összeegyeztethetetlen vallás (Albouy 1969, 162. o.).

Prométheusz alakja a 19. századi francia költészetben is megjelent. Louis Ménard költészetében Prométheusz a racionalizmus hősévé válik és a tudományt dicsőíti. A megszabadult Prométheusz egy ifjúsági mú. Prométheusz a Kaukázuson várja a kiszabadítását, szóba elegyedik az emberiséget jelképező kórussal beszélget és megvizsgálja a Jupitertől Krisztusig egymást követő vallásokat (Albouy, 1969).

Louise Ackermann költőnő Prométheusz című alkotása egy beszédből áll, melyet a titán Jupiterhez intéz. Az egyetlen bűn, melyet Prométheusz bevall, az az emberek iránta sajnálata, akiknek Jupiter nyomorúságos sorsot szánt. Ennek ellenére Prométheusz segítette őt a titánok elleni harcban mivel véget akart vetni az ősi istenek által képviselt vallásnak és azokat a szeretet istenével akarta helyettesíteni. Egy olyan Jupiterről álmodott, aki szerette a teremtményeket (Albouy, 1969, 165. o.).

André Gide munkásságában Prométheusz romantikus vagy pozitivista mítosza eltűnni látszik, ehelyett az én mítosza jön létre. Itt Prométheusz aktívabb szereplő és a felszabaduló ént jeleníti meg. Az emberiséget felszabadító Prométheusz helyébe az individualizmus hőse lép (Albouy, 1969, 166. o.).

Élémir Bourges regényíró írásaiban Prométheusz igyekszik megszabadítani az embereket a rossztól. Hiába éleszti fel a lélek hét lángját, mindegyik lángot sötétség oltja el. Ekkor Zeuszhoz fordul de egyik vallás - deizmus, 
panteizmus - sem felel meg neki, mindegyik elősegíti a rossz fennmaradását. Prométheusz elhatározza, hogy új embert hoz létre, agyagból gyúrja össze, az intelligencia egyetlen fehér lángjával próbálja vezetni, nélkülözve a vágy piros lángját. Nem sikerül neki, fia vakon születik. Gyermekét karjában tartva Prométheusz eltávolodik a fény keresésétől (Albouy, 1969, 170. o.). R. Trousson így vélekedik erről a befejezésről: „A mű konklúziója megőrzi az ész és a hit kettős bukását. Bourges Prométheusza valójában lemond a megoldás utópiájáról, mely gyógyír lenne az emberiség aggodalmára de nem mond le a keresésről" (idézi Albouy, 1969, 170. o.). Ez a felfogás Camus Prométheuszának előfutára, aki remény nélkül de nem boldogság vagy bátorság nélkül görgeti a szikláját (Albouy, 1969).

\section{Történelmi hatások}

Felmerül a kérdés, hogy egy 20. századi francia író miért tér vissza a görög mitológiához múve megírásakor. Camus nevéhez füződik az abszurd, mely más műveiben, mint például a Sziszü̈phosz mitosza című esszéjében is megtalálható. Ez az életérzés, mely a hiábavalóságot, az emberi lét értelmének keresését jelenti, összefüggésbe hozható az író által megélt kor történelmi hátterével, gondolok itt a második világháborúra és az algériai háborúra.

A második világháború során a franciákat számos veszteség érte, különböző problémákkal kellett szembesülniük. A második világháború 1939. szeptember 3-ikán tört ki, amikor Németország megtámadta Lengyelországot, 1940 május 10-én pedig a Wehrmacht elindította a nyugati offenzívát. A németek öt hét alatt 1850000 hadifoglyot ejtet- tek, 92000 francia és angol esett el. Június 16án Reynauld lemondott Pétain javára, aki rádióbeszédében fegyverszünetet jelentett be.

A németek célja az volt, hogy Franciaország ne legyen hadviselő fél, a francia hadsereg létszámát százer főben szabták meg. Nagy csapás volt Franciaországnak, amikor megszállás alá kerültek a legnagyobb és legsűrübben lakott területei, 1940 augusztusában Elzászt és Lotharingiát újra a Birodalomhoz csatolták, amiből a német hadseregbe történő besorolás és durva németesítés következett.

A második világháború tehát nagy hatással volt a francia nép életére de Camus munkássága összekapcsolható az algériai háborúval is, melynek során az algír nacionalisták kerültek szembe a Francia Állammal. Ez a konfliktus a második világháborút követő dekolonizáció részét képezte. Vietnám függetlenségének kikiáltása, a franciák által elszenvedett vereség bátorítást jelentett a többi, gyarmatokon élő nép számára. Az algériai háború traumát okozott a francia nép számára, nyolc éven át tartott és elhozta a IV. Köztársaság időszakát.

Az 1950-es évek Franciaországának Algéria elvesztése magas rangjának és nagy hatalmának elvesztését is jelentette. Az algírok számára a fegyveres harc egy igazi kiábrándulást jelentett a francia ígéretekből.

Ami Camus Prométheusz a pokolban címú írását illeti, alapvetően filozófiai esszék közé sorolják de Olivier Todd szerint ,inkább erkölcsi, mint filozófiai kérdéseket boncolgat." (Todd, 2003, 420.o.). Emellett inkább erkölcsi, mint etikai problémákról van benne szó, amennyiben az erkölcs célja az élet szabályainak megalkotása, az etika feladata pedig az erkölcsi fogalmak elemzése és egy olyan erkölcs megteremtése, mely nem Istenre vagy 
valamilyen transzcendenciára hivatkozik. (Todd, 2003, 420. o.).

\section{A lázadás és ellenállás motívuma}

Prométheusz mítoszának alapvető eleme a lázadás: tulajdonképpen lázadott,amikor megteremtette az embereket és megtanította óket szántásra-vetésre, írásra, mesterségekre, sőt elhozta nekik a tüzet. Hatalmat adott nekik a tudás és a tűz által - ez egy lázadás volt az istenek ellen. Prométheusz története mellett a Sziszüphosz mitosza című filozófiai esszében is megjelenik a lázadás, sőt $A$ lázadó ember címú mú alapját képezi.

Hogy Camus miért fordított ekkkora figyelmet a lázadásra, azt Nicolae Balotă az Ellenállással hozza összefüggésbe, itt láthatjuk tehát, hogyan kapcsolódhat össze az író munkássága és a történelmi háttér. Ahogy Balotă Az abszurd irodalom címú könyvében olvashatjuk, Camus már a francia összeomlás első napjaitól kezdve ellenezte az együttműködést a nácizmussal, algériai újságírói tevékenysége során pedig több cikket is közölt, melyekben, ahogy Balotă fogalmaz, ,igyekszik összebékíteni a mindenféle egyéni lét abszurditásának tudatát a hódítókkal szembeni közös ellenállás akaratával, mely nem maradhat csupán óhaj, mivel a lázadás - akárcsak az abszurd - nem puszta fogalmi adottság, s nem is pusztán a szenzibilitás tapasztalata" (Balotă, 1979, 258. o.).

Az Ellenállással kapcsolatos a Lettres à un ami allemand című négy levél, melyet egy német barátnak címez, melyben ugyanakkor arról is képet kapunk, hogyan ítéli meg Camus saját felfogása szerint az abszurd hôsiességet és az abszurd elleni lázadás lehetőségét (Balotă 1979). Az Ellenállás és az abszurd közötti ha- sonlóság abban rejlik, hogy mind a kettő önértékkel és önmagán túlmutató céllal rendelkezik. Az Ellenállás sem volt öncélú, ahogyan az abszurd sem. Balotă szerint az abszurd igazságtalanságnak megállapítása során olyan új igazság, értelem és érték keresésérôl van szó, mely igazol valamilyen tettet (Balotă, 1979, 259. о.).

Ez jellemzi az olyan mitológiai alakokat is, mint Prométheusz. Azáltal, hogy megteremtette az embereket és képességeket, illetve tudást adott nekik, új értéket is teremtett, mely szerint nemcsak istenek létezhetnek, nemcsak Zeusz teremthet, nemcsak az istenek rendelkezhetnek különböző képességgel. Ez a fajta lázadás egyértelműen önmagán túlmutató céllal rendelkezik, hiszen Prométheusz az emberiség javát szolgálta, nem saját önző céljai vezérelték. Ez az új igazság természetesen nem nyerte el a főisten tetszését, ezért büntette meg Prométheuszt, ezért láncolta a Kaukázus szikláihoz. Mint ismeretes, Héraklész segítségével szabadulhatott ki, aki lelőtte a keselyűt. Bár ezt annak köszönhette, hogy Hermész elmondta apjának, Thetisz fia hatalmasabb lenne nála, ha megszületne. Ez a magatartás egy új igazságot képvisel: csak azért, mert Prométheusz új lényeket teremtett, amiért továbbadta az értékes tudást, amiért megsértette az istenek hiúságát, még nem kell bűnhődnie, attól még lehet értelme annak, amit cselekedett.

Mint láthatjuk, az abszurd és a lázadás szorosan kötődnek egymáshoz Camus írásaiban, Nicolae Balotă viszont megmutatja az abszurd és a lázadás között fellelhető különbségeket: „Ezen a ponton válik el egyébként a lázadó ember az abszurd embertől. Persze kétségbeesése, az a határhelyzet, amiből a lázadó kiindul, az abszurd érzéséhez hasonlóan »álta- 
lában mindenre és különösképpen semmire sem vonatkozik«. De amíg az abszurd univerzumban a képtelenséggel, a nemléttel, az értékhiánnyal azonosul az ember, a lázadás világában fölismeri, hogy van olyan adottsága, mellyel érdemes azonosulnia: »a lázadás bármely mozdulata hallgatólagosan értéket idéz« (Balotă, 1979, 320. o.). Megjegyzi továbbá, hogy az elvont abszurddal szemben a lázadásnak konkrét célja van, ez lehet többek között az istenek trónfosztása is vagy bármiféle harc az elnyomás, az idegen ellen. Prométheusz esetében is az istenek trónfosztásáról van szó és meglehetôsen hasonló ez arra, amit Camus átélt: a német megszállás Franciaországban, az esetleg szövetkezés a nácikkal, ahogy Prométheusz az istenek akaratának mond ellent, úgy mond ellent Camus a megszálló hatalomnak, az elnyomásnak (Balotă 1979).

Miért lehet a lázadás olyan fontos Camus számára? Miért jelenik meg számtalan szövegében, miért jellemzi szereplőit a lázadás, miért lázad ő maga is újságíróként? A lázadó ember címú műve adhatja meg erre a választ, ott ugyanis az ember negatív definiálása történik: „Az ember az egyetlen teremtmény, mely nem hajlandó az lenni, ami” (idézi Balotă, 1979, 320. o.). Ez alapján a kijelentés alapján elmondhatjuk, hogy a lázadás teszi emberré az embert. Mi magunk is egyetérthetünk Camus megállapításával ha arra gondolunk, hogy csak az ember hajlandó és képes nemet mondani, az ember képes forradalmat indítani a változásért, államot létrehozni és átalakítani, szellemi mozgalmakat indítani, ahogy tették azt a költők, írók, filozófusok, egyre nagyobb és nagyobb tudásra vágyni és arra szert tenni.
Sem Prométheusz, sem Camus nem fogadja el teljesen azt, ami. A lázadás ugyanakkor nemcsak antropológiai szempontból fontos Camus számára, hanem azért is, mert ez az egyetlen és elsődleges evidencia a bizonytalan világban. Prométheusz abban nem lehet biztos, hogy az istenek miről hogyan rendelkeznek, abban sem lehet teljesen biztos, hogy mi lesz az emberekkel miután megalkotta őket. Abban viszont biztos lehet, hogy tud lázadni az istenek ellen, megtehet valamit, amit saját erkölcsei diktálnak, akkor is, ha nem látja pontosan annak következményeit, akkor is ha bűnhődni fog miatta.

A lázadás motívumának fontossága nem véletlenül került elő éppen Camus múveiben, éppen a második világháború alatt. A háborúban sem volt más bizonyosság, csak a lázadás, nem lehetett tudni, ki nyeri a háborút, nem lehetett tudni mikor lesz vége Franciaország német megszállásának, nem lehetett tudni, hol húzódnak majd a francia és német határok. Ha igazságtalanságra került sor, amelyet a franciák nem tudtak elviselni, nem tehettek mást, minthogy lázadnak ellene. Erről Balotă a következőket fogalmazza meg: „A lázadás reménytelen (akárcsak az abszurd), de nem kétségbeesett. Ellene szegül minden ítéletnek (...) és a halállal vádolt mindenféle cinkosságnak. A Camus-féle kategorikus imperativus így hangzik: az embernek ki kell nyílvánítania igazát, hogy harcoljon az igazságtalanság ellen, hogy por oposición megteremtse a boldogságot, hogy tiltakozzék a boldogtalanság világa ellen” (Balotă, 1979, 329. o.).

\section{Metafizikai lázadás}

Prométheusz esetében fontos kiemelni a metafizikai lázadás fogalmát, mely abban áll, 
hogy az istenek ellen lázad, ellenük követ el bűnt és ôk büntetik meg. A metafizikai lázadás nem-csak Prométheusz mítoszában és Camus mű-veiben jelenik meg. Balotă is utal rá, hogy az újkort a prometheizmus uralja, illetve további példákat említ: a 17. század libertinusai, Sade, a romantikus dandyk, Stirner, Dosztojevszkij, Nietzsche (Balotă, 1979).

Camus és a mitológiai alakok esetében nemcsak metafizikai lázadásról, hanem ezzel együtt metafizikai nyugtalanságról is beszélhetünk, melyről Olivier Todd szerint Camus előtt senki nem beszélt ilyen következetesen.

Ez a metafizikai nyugtalanság tökéletes öszszhangra vágyik ember és világ között. Ez mutatkozik meg Prométheusz esetében is, aki egy olyan világra vágyik, ahol nemcsak az istenek akarata érvényesül, ahol az istenek és emberek megférnek egymás mellett, ezért teremtette meg az embereket és ruházta fel óket különböző képességekkel. Ugyanez a metafizikai nyugtalanság már nem jellemzője az isteneknek, akik szerint minden jól van a világban, csak a saját hatalmuk számít.

Bár Prométheusz története az ókorba nyúlik vissza, a 20. századot sem kerülte el a metafizikai nyugtalanság: a franciák egy része nem tudta elfogadni a német megszállást, a háború alatt a németek öt hét alatt 1850000 hadifoglyot ejtettek, 92000 francia és angol esett el, a világ nemzetei nem tudtak békében élni egymás mellett, ártatlanok pusztultak el. A kor embere joggal tehette fel a kérdést: miért velünk történik mindez? Hová tűnt az eddigi béke? Miért kell ellenségként léteznünk, ha mind ugyanolyan emberek vagyunk, legyünk bár angolok/franciák/németek? Egy ilyen világban teljesen egyértelmû az összhang hiánya. Ez a feszült hangulat hatott természe- tesen Camus-re is, aki Todd szerint „ártatlan gyermekek halálának botrányával szembesült, amikor teológiával foglalkozott, majd később olyan politikai elvekkel találta szembe magát, melyeket újságíróvá válva elvetett" (Todd, 2003, 428. o.). Todd idézi Camus-t, aki mindezekről az alábbiakat írta: „Aki szívén viseli a világ sorsát, azt szorongással tölti el a kultúrák összecsapása. Én is átéltem ezt a szorongást, miközben részt kértem a játszmából. (...) Választani kell szemlélődés és cselekvés közt." (idézi Camus-t Todd, 2003, 422. o.). Todd magyarázata szerint az abszurd egy olyan érzés, mely meghatározza az ember testi valóját és kitölti a világmindenség egészét. Olyan példákat említ könyvében, melyeket Camus használt az abszurd illusztrálására: az idő múlásában fedezhető fel az abszurd, például amikor telefonfülkében hadonászó embert pillantunk meg vagy a halál elkerülhetetlenségével szembesülünk (Todd, 2003). Camus szerint az abszurdot csak az alkotó képes annak legszélsőségesebb formájában megjeleníteni. Todd szerint ez nem minden művészre igaz, Camusnek viszont kifejezett képessége (Todd, 2003, 428. o.).

Camus mitológiai példái, filozófiai esszéi valóban a szélsőségeket mutatják be. Az ártatlanság és a bűnhődés, a boldogság és a boldogtalanság, az élet és a halál mind olyan szélsőségek, melyek megtalálhatók műveiben. Prométheuszról írt esszéjében az ártatlan Prométheusz és az őt szenvedésre ítélő Zeusz, Prométheusz kiszolgáltatottsága és Zeusz hatalma, az emberek teremtése és Prométheusz ideiglenes - pusztulása állnak egymással szemben.

Ami Camus nyelvezetét és az abszurd definiálását illeti, ennek köze van némileg a francia 
nyelvhez is, ahol úgy tűnik, hogy két jelentése van az abszurdnak, az angolban viszont az absurd és a nonsensical szavak fejezik ki ugyanezt. Számára az abszurd jelentheti a következőket: ellentmondó, álságos, értelmetlen. Todd szerint Camus „érvelése gyors, világos, tiszta. Egyfajta tisztánlátást keres, de nem jut el addig, csak érintőlegesen beszél a XX. század világfájdalmáról”' (Todd, 2003, 426. o.).

\section{„Déli gondolkodás”}

A „XX. század világfájdalmához” hozzátartozik az, amit Camus „déli gondolkodásnak” nevez. Ez az eszmény természetesen a korábban már felvázolt történelmi háttérből is ered, illetve az abszurd életérzésből, a világ és ember egyensúlyának kereséséből. Ahogy Mészáros Vilma fogalmaz, a déli gondolkodás éppen a középutat keresi és el akarja kerülni a választást. A világ és társadalom ellentéte kapcsán ezt úgy fogalmazza meg, hogy a déli gondolkodás ,igent mond a világnak, nemet a társadalomnak, mindkettőt erősen érzelmi alapon” (Mészáros, 1973, 150-151. o.).

Ugyanezt az eszményt Prométheusz mítoszával is összefüggésbe hozhatjuk, mivel Prométheusz igent mondott a világnak és nemet az isteneknek, akik az emberek megteremtése előtt a tulajdonképpeni társadalmat jelentették, hiszen ők döntöttek a világ sorsáról, bár léteztek titánok is, de az istenek felsőbbrendűek voltak, az istenek között pedig egyfajta hierarchia állt fenn. Prométheusz az emberek megteremtése által igent mondott a világnak és nemet az isteneknek.

A déli gondolkodás nem híve az intézményeknek, az egyedinek viszont igen. Bár Prométheusz esetében nem konkrét intézményről volt szó, hanem az istenek akaratáról és korlátlan uralmáról, ellentmondott nekik. $\mathrm{Az}$ istenek „uralma” tulajdonképpen egy intézményhez hasonlítható, hiszen szabályokat hoztak, mások felett áltak. Prométheusz viszont az ember teremtésekor valami egyedit hozott létre, valamit, ami neki köszönhetően született, amit az istenek nem befolyásoltak. Mint a mítosz is mutatja, Prométheusznak ezért kellett bűnhődnie, míg Hermész ki nem szabadította.

Mészáros Vilma továbbviszi gondolatmenetét azáltal, hogy azt állítja, Camus ,elidegenültnek tekint minden fogalmat, amely az önmagában vett egyénnel szemben áll: hívják azt istennek vagy történelemnek" (Mészáros, 1973, 150-151. o.). Ahogy az idézetből kiderül, nemcsak az isteneket ellenzi, hanem a történelmet is.

\section{A történelem szerepe}

Ahhoz, hogy értelmezzük a történelem szerepét, vizsgáljunk meg különböző történelem-fogalmakat!

Erich Frank a történelmet így határozta meg: „A helyzet, amelyben az egyén találja magát, annak eredménye, amit ő és előtte mások átéltek, tettek és gondoltak, visszavonhatatlan döntéseké tehát. Egyedül a múltnak tudható be, hogy az ember gondolkozni, cselekedni és létezni tud (ha számot vet ezzel a múlttal). Ebben áll létezésének történetisége" (Frankot idézi Kéri, 1997).

A történelem tehát annak eredménye, amit az adott ember és mások a múltban tettek, gondoltak és átéltek, visszavonhatatlan döntések következménye. Ez, a történelemben rejlő visszavonhatatlanság az istenek döntéseinek visszavonhatatlaságával is párhuzamba állítható. Ahogy egy hétköznapi ember, például 
Camus korában, nem másíthatja meg politikusok, uralkodók, híres hadvezérek döntéseit, úgy Prométheusz sem menekülhet az istenek elhatározása elől, nincsenek beleszólása az események alakulásába.

Arthur Schopenhauer szerint „Az ember (...) - eltérően az állattól - az észnek köszönhetően nem korlátozódik a szűk, szemléleti jelenre, hanem megismeri a hasonlíthatatlanul messzebbre ágazó múltat is, mellyel össze van kapcsolva és melyből származik; de csak ennek révén szerez tulajdonképpeni ismeretet magáról a jelenről, s még a jövőt illetően is következtetéseket vonhat le" (Schopenhauert idézi Kéri, 1997).

Bár alapvetően a történelem ismerete segít a jelent jobban megértenünk, illetve a jövôvel kapcsolatban hipotéziseket állíthatunk fel, ha a múltra már van rálátásunk, a történelem mindeközben, paradox módon, egy korlátozó erő is, hiszen a jelen és a jövő nem kerülheti el a múlt befolyását.

Emellett egy harmadik történelemfelfogást is érdemes itt megemlíteni, mely Friedrich Nietzschétől származik és azt állítja, az ember háromféleképpen viszonyulhat a történelemhez: „igényli, mint tevékeny és törekvő lény, mint megőrző és tisztelő lény, s mint szenvedő és szabadulásra szoruló lény. A viszonyulás e hármasságának a történelem tanulmányozási módjának hármassága felel meg: ha tetszik monumentális, antikvárius és kritikai történetírást különböztetünk meg" (Nietzschét idézi Kéri, 1997). Prométheuszra is vonatkoztathatnánk ezeket az állításokat, hiszen törekszik a környezete megváltoztatására, a világ jobbá tételére, ennek következtében pedig később szenvednie kell, végül pedig megszabadul a rabságból. A Nietzsche által felsorolt három magatartás viszont az íróra, Camus-re is illik. Tevékeny és törekvő, hiszen újságíróként tevékenykedik Algériában, irodalmi és filozófiai műveiben igyekszik a világ abszurditására rámutatni, a németekkel való együttműködés ellen tiltakozik, a béke elérése a célja. Megőrzi és tiszteli ugyanakkor a történelmet, hiszen a görög mitológia jelentős szerephez jut különböző műveiben és pártolja a déli gondolkodást. Ezzel egyidőben szenved is és szabadulásra szorul. Szenved a világháború miatt, melynek következtében menekülni kényszerül, nem érezheti magát teljesen biztonságban, el kell viselnie a béke hiányát, a kultúrák összecsapását, amit olyannyira ellenzett.

Camus így nyilatkozik a történelemrôl a Prométheusz a pokolban című esszéjében: „A történelem terméketlen föld, amelyen nem nő hangafü. A mai ember mégis a történelmet választotta, és nem tudott, nem is kellett elfordulnia tőle. De ahelyett, hogy igájába kényszerítené, mindennap egy kicsit jobban belenyugszik, hogy az tegye rabszolgájává ôt. Ezzel árulja el Prométheuszt, e »merész gondolkodású és könnyű szívű« fiút" (Camus, 1990, 147. о.).

Esszéjében Camus összehasonlítja az isteneket, akik Prométheuszt szenvedésre ítélték, saját korának emberiségével és nem túl pozitív a kép, melyet kortársairól fest: „Ha Prométheusz visszatérne, az emberek ma is ugyanúgy tennének, mint egykor az istenek: sziklához láncolnák, ugyanannak az emberségnek a nevében, amelynek ô a legfőbb szimbóluma. A legyőzöttet becsmérlő ellenséges hangok ugyanazok volnának, mint amelyek idáig visszhangoznak a szkítiai tragédia küszöbéről: az Erô, és az Erőszak hangjai" (Camus, 1990, 146. о.). 


\section{A tüz motívuma}

Ezen a ponton célszerű kiemelni Prométheusz mítoszából a tûz motívumát. A mesterségek és különböző képességek, ismeretek mellett Prométheusz a tüzet is az embereknek ajándékozta, pontosabban az istenektôl lopta el. A tűz hatalmat is jelent az emberek számára, egy erôt, mellyel - immár - csak ők rendelkeznek. A tûz képes kissé enyhíteni az istenek korlátlan hatalmát, akár védelmet biztosíthat az embereknek.

A mû megírásakor, a második világháború korában az emberiségnek ugyanerre volt szüksége: valamire, ami csökkenti a kiszolgáltatottságot, ami védelmet nyújthat, ami képes eltörölni a régi rendet és elősegíteni a fejlődést. Békére volt szükség a Camus által is megélt kaotikus, fenyegető, bizonytalan világban.

Ha a történelmi hátteret is figyelembe veszszük, azt is gondolhatjuk, hogy a tűz nemcsak a tudást szimbolizálja, hanem ettôl sokkal többet. A tűz lehet a béke vagy akár a szeretet szimbóluma is, elég csak a béke lángjára gondolnunk vagy egy égő gyertya meghittségére. A tűz ezzel együtt értelmezhetô úgy is, mint a világosság, a sötétség ellentéte, az értelem, a fejlődés, hiszen, többek között, a felvilágosodás szavunk is a világosság szimbolikus jelentését veszi alapul.

A tűz metaforáját továbbgondolva eszünkbe juthat a tűz terjedése, mert, bár errôl nem esik szó Prométheusz mítoszában és Camus esszéjében, a tűz, ha a tudás, a béke jelképeként gondolunk rá, akkor jelenthet valami olyat, mely gyors terjedésével képes a világban egyre messzebbre hatolni, a szeretet, a béke, az értelem segítségével pedig terjedés közben fokozatosan lebontani azt a világot, ahol -
Camus korában például - a háború, ellenségeskedés, a meghittség hiánya uralkodik.

\section{Zárógondolatok}

A tanulmány, egyebek mellett, a történelmi hátteret használta fel a szöveg elemzéséhez de a Camus által megélt történelmi események mit sem változtatnak a mítosz aktualitásán. Camus más műveihez hasonlóan, az itt elemzett esszé sem veszít mondanivalójából: a lázadás, a szabadság kérdése, azok lehetősége, illetve korlátai, az ember és világ közötti egyensúly és annak hiánya mindig gondolkodásra ösztönözhetnek bennünket. Ez adja Camus munkásságának igazi jelentőségét, hiszen művei minden korban megállják a helyüket, minden korosztály, társadalmi csoport, nemzetiség számára hordozhat mondanivalót. Olyan kérdésekkel foglalkozik, melyek, bár a 20. században vetette őket papírra, ma is feltehetnénk őket: lesznek-e még Prométheuszok, akik nekünk adják a tüzet, lesz-e még egyáltalán tűz? Vajon észrevesszük-e a mítoszok mögött rejlő üzenetet, képesek leszünk-e úgy remélni, gondolkodni, cselekedni, ahogy Camus tette?

A francia író filozófiai esszéjében ki is fejti ezzel kapcsolatos véleményét: „A mítoszoknak nincs saját életük. Arra várnak, hogy életet öntsünk beléjük. Elég, ha egyetlen ember felel hívásukra, és máris kínálják érintetlen életerejüket. Óvnunk kell a mítoszt, nem szabad hagynunk, hogy álma halálos legyen, mert csak így lesz lehetséges a feltámadás. Néha kétlem, hogy a mai embert meg lehet még menteni. De a gyerekeit igen, testileg és szellemileg is. Lehetséges egyszerre kínálni nekik a boldogság és a szépség esélyeit.” (Camus, 1990, 148. o.). 
Prométheusz mítosza kitüntetett helyet foglal el a mítoszok között, erre magyarázatot is találunk a múben: „(...) Prométheusz mítosza azon mítoszok egyike, amelyek emlékeztetni fognak rá, hogy az embert csak átmenetileg lehet megnyomorítani, és hogy semmivel sem szolgáljuk, ha nem egészen szolgáljuk ôt" (Camus, 1990, 148. o.). Miért éppen Prométheusz mítosza kap kitüntetett figyelmet? Az előbbi idézetből láthattuk, milyen szerepet szán az író Prométheusz mítoszának az utókorra vonatkoztatva de mûvében megtaláljuk a mitológiai alak jellemzését, mely annál inkább megvilágítja miért különleges Prométheusz: „A leláncolt titán az isteni villámlás és mennydörgés közben is megőrzi hitét az emberben. Ettől keményebb, mint a kőszikla, amelyhez oda van láncolva, és türelmesebb a máját tépő saskeselyűnél.” (Camus, 1990, 149. o.).

\section{Irodalom}

Albouy, P. (1969): Mythes et mythologies dans la littérature française. Paris (Fr.): Librairie Armand Colin
Balotă, N. (1979): Abszurd irodalom. Gondolat Kiadó, Budapest

Camus, A. (1990): Sziszü̈hosz mitosza. Válogatott esszék, tanulmányok. Magvető Kiadó, Budapest.

Csiffáry T. (2008): Mitológiai lexikon. A-tól Z-ig. Könyvmíves Könyvkiadó, Budapest

de Luppé, R. (1958): Albert Camus. Paris (Fr.): Éditions Universitaires, Paris.

Eliade, M. (2014): A szent és a profán. Helikon, Szekszárd.

Kéri K. (1997): Mi a neveléstörténet? JPTE

Tanárképző Intézet, Pécs. Letöltés:

2020.03.17. Web:

https://mek.oszk.hu/01800/01886/html /nter4408.htm

Louviot, M. (2013): Mythe et littérature.

Copyright Éditions Didier

Mészáros V. (1973): Camus. Gondolat Kiadó, Budapest

Todd, O. (2003): Albert Camus élete 1. Európa Könyvkiadó, Budapest. Letöltés:

2020.03.17. Web:

https://www.larousse.fr/encyclopedie/di vers/Seconde_Guerre_mondiale/122570 